\title{
New laccase-producing fungi isolates with biotechnological potential in dye decolorization
}

\author{
Raúl Tapia-TusselI ${ }^{1 \star}$, Daisy Pérez-Brito ${ }^{1}$, Rafael Rojas-Herrera², Alberto Cortes-Velazquez ${ }^{1}$, \\ Gerardo Rivera-Muñoz ${ }^{3}$ and Sara Solis-Pereira ${ }^{3}$ \\ ${ }^{1}$ Laboratorio GeMBio, Centro de Investigación Científica de Yucatán A.C., Calle 43 \# 130, Chuburná de Hidalgo, C.P \\ 97200, Mérida, Yucatán, México. \\ ${ }^{2}$ Facultad de Ingeniería Química, Campus de Ingenierías y Ciencias Exactas, UADY, Periférico Norte Kilometro 33.5, \\ Tablaje Catastral 13615, Col. Chuburna de Hidalgo Inn, C.P. 97203. Mérida, Yucatán, México. \\ ${ }^{3}$ Instituto Tecnológico de Mérida, Av. Tecnológico km. 4.5, Mérida Yucatán, México.
}

Accepted 1 June, 2011

\begin{abstract}
Thirty six (36) native fungal strains from the state of Yucatan were first screened for ligninolytic activity on solid media containing ABTS. Molecular identification based on ITS rDNA region and PCR fingerprinting of seven selected fungi isolates were carried out. Molecular characterization based on genetic fingerprinting was helpful in determining unequivocally the differences between isolates at genera and species levels. The seven isolates showed ABTS oxidation zones in plates but only five strains produced extracellular laccase. The strains identified as Trametes hirsuta (GenBank accession numbers GQ280372 and GQ280373) showed the highest laccase production. The strain Bm-2 displayed the greatest laccase activity and dye decolourization ability in $72 \mathrm{~h}$ without the addition of mediators. Both the high laccase activity shown by $\mathrm{Bm}-2$ and its ability to decolorize dyes are a good indication of its possible use in the treatment of textile effluents.
\end{abstract}

Key words: Laccase, Trametes hirsuta, dye decolorization, PCR fingerprinting.

\section{INTRODUCTION}

Biological processes represent a good alternative for remediation and decontamination of environmental pollutants given the ability of some microorganisms to mineralize a wide variety of toxic xenobiotics and to oxidise substrates with low solubility, such as chlorinated phenolics, synthetic dyes, pesticides and polycyclic aromatic hydrocarbons (Baldrian, 2006; Reddy, 1995; Rodriguez et al., 1999; Torres et al., 2003). White-rot fungi including Trametes, Pleurotus, Coriolopsis and other genera, degrade a variety of dyes without generating toxic by-products. Studies on these organisms have identified laccase as a significant component of their enzyme system (Levin et al., 2004; Peláez et al., 1995). The effectiveness of the process using laccase has been proven and colour removal from 40 to $95 \%$ in

*Corresponding author. E-mail: rtapia@cicy.mx. Tel: (0052) 999-942-8330. Fax: (0052) 999-981-3900. common textile dyes has been demonstrated (Cristovão et al., 2008; Rodriguez et al., 2005; Tavares et al., 2009).

Identification and characterization of fungi species and strains is based on morphological, physiological, biochemical and genetic characteristics. The whole procedure is time-consuming and technical skills are required for proper interpretation of results (Fleet, 1992). On the other hand, DNA-based identification is faster and more reliable than phenotypic characterization (Kurtzman et al., 2003). By using PCR-based methods, fungi can be identified to the level of genus, although, the identification to species level is dependent on the choice of a specific method. Appropriate molecular methods for identification of fungi species and strains are PCR-fingerprinting, RAPDs and restriction analysis of non-coding ribosomal DNA (rDNA) (PCR-RFLP of internal transcribed spacer [ITS]), cleaved amplified polymorphic sequence and simple sequence repeats (SSRs). The efficacy of identification can be greatly increased when combinations of these methods are used (Leaw et al., 
2006; Perez-Brito et al., 2007; Tapia-Tussell et al., 2008).

In developing countries, many textile-manufacturing industries release dyes into the environment, leading to the accumulation of highly undesirable pollution load in water bodies. As a result of their recalcitrance to biological degradation, these pass into the environment on a large scale. Adding to this problem is the fact that the dyes are aromatic in nature and contain a variety of linkages. Biodegradation, using enzymes such as laccases has been suggested as one of the most attractive alternatives for treatment of dyes (Robinson et al., 2001). However, in most fungi the yield of laccases is too low for commercial purposes even when their genes are expressed in various heterologous hosts (Hong et al., 2006). Therefore, it is of great benefit to explore new strategies for overproduction of lacasses or to screen new microorganisms with high yields of the enzyme. In Yucatan, Mexico, in particular, many of textile industries are posing an environmental problem mainly because of the peculiar characteristics of soil structure and shallow underground water. In the search for fungi strains well adapted to the environmental conditions of the region and with high laccase activity to be used in effluent decontamination, the aim of this study was to screen selected Yucatan native fungi for their ability to decolourize effluent and textile dyes and to carry out the molecular characterization of these fungi.

\section{MATERIALS AND METHODS}

\section{Fungi isolation}

Fruiting bodies fungi were collected from henequen by-products in a processing factory (12 isolates) and wood decay (24 isolates) in different municipalities of the state of Yucatan (Hunucma, Baca, Dzemul and Merida). Isolation was carried out on plates of ME medium containing $2 \%$ malt extract, $250 \mu \mathrm{g} / \mathrm{l}$ amikacin, $6 \mathrm{mg} / \mathrm{l}$ Benlate $\AA$ (in order to prevent the growth of filamentous fungi) and $2 \%$ agar. Plates were incubated at $35^{\circ} \mathrm{C}$ for 3 to 5 days. Fungi were subcultured three times to obtain stable, pure cultures.

\section{Primary screening for ligninolytic activity}

As an initial screening method for detecting the ability of fungal strains to produce lignin modifying enzymes, an ABTS (2,2'-Azinobis(3-ethylbonzotiazoline-6-sulfonic acid) diammonium salt) oxidation based method was used (Matsumura et al., 1987). A disk of $1 \mathrm{~cm}$ diameter of mycelium from each strain was inoculated on ME plates containing $5 \mathrm{mM} \mathrm{ABTS}$ and then incubated for four days at $35^{\circ} \mathrm{C}$. The formation of a dark-green halo in ME plates indicated a positive extracellular laccase secretion. The diameter and intensity of the halo were used as an indicator of the level of ligninolytic enzyme production. Strains with a dark-green colouration appearing on the second day of incubation and with a ratio above $1 \mathrm{~cm}$ were classified as highly ligninolytic and were chosen for further molecular identification and characterization.

\section{PCR-fingerprinting}

Arbitrarily, primed (AP)-PCR was carried out using seven $15 \mathrm{bp}$ primers according to previous reports: $(\mathrm{GTG})_{5},(\mathrm{GAC})_{5}$ and $\mathrm{M} 13$ (5'GAGGGTGGCGGTTCT-3') were used at $50^{\circ} \mathrm{C}$ of annealing temperature (Perez-Brito et al., 2007; Cadez et al., 2002); (TCC) and $(\mathrm{GACAC})_{3}$, were used at $42^{\circ} \mathrm{C}$ (Bridge et al., 1997) and (CAG) $)_{5}$ was used at $60^{\circ} \mathrm{C}$ (Talhinhas et al., 2002). PCR reactions were performed in $25 \mu \mathrm{l}$ reaction volumes containing PCR buffer $(20 \mathrm{mM}$ Tris- $\mathrm{HCl}, 50 \mathrm{mM} \mathrm{KCL}, \mathrm{pH}$ 8.4), $0.25 \mathrm{mM}$ of each of dNTPs (Invitrogen), $2 \mathrm{mM} \mathrm{MgCl}, 0.8 \mu \mathrm{M}$ of each primer, $10 \mathrm{ng}$ of template DNA and $1 \mathrm{U}$ Taq polymerase (Invitrogen). DNA amplification was performed in a GeneAmp 9700 DNA Thermal Cycler (PerkinElmer), with an initial denaturing step of $5 \mathrm{~min}$ at $95^{\circ} \mathrm{C}$, followed by 40 cycles of $40 \mathrm{~s}$ at $95^{\circ} \mathrm{C}, 60 \mathrm{~s}$ at the appropriate annealing temperature for each primer and $60 \mathrm{~s}$ at $72^{\circ} \mathrm{C}$; and a final extension step of $5 \mathrm{~min}$ at $72^{\circ} \mathrm{C}$. Amplified DNA fragments were separated by electrophoresis in 1.5\% (w/w) agarose gels (Invitrogen), in 1X TBE (0.9 M Tris-Borate-20 mM EDTA) buffer at $100 \mathrm{~V}$ for $40 \mathrm{~min}$ and stained with ethidium bromide. DNA banding patterns were visualized on a UV transilluminator and images were acquired with UVP Biolmaging systems.

\section{Production of laccase}

Cultures of the seven selected fungi were maintained on liquid basal medium, pH 6 (Tien and Kirk, 1984). Erlenmeyer flasks containing $50 \mathrm{ml}$ of media were inoculated with $1 \mathrm{ml}$ of homogenized mycelia, from inoculums previously produced in liquid ME medium, and incubated for $96 \mathrm{~h}$ at $35^{\circ} \mathrm{C}$ on a rotary shaker (150 rpm). Cultures were harvested, filtered and centrifuged at 7 $800 \times g$ for $20 \mathrm{~min}$ to remove mycelia and the supernatant was used to measure the laccase activity by oxidation of ABTS (Pal et al., 1995). Reaction mixture contained $1 \mathrm{M}$ acetate buffer $\mathrm{pH} 5$ (100 ul), $5 \mathrm{mM}$ ABTS $(100 \mu \mathrm{l})$, deionized water $(700 \mu \mathrm{l})$ and enzyme extract $(100 \mu \mathrm{l})$. Oxidation of ABTS was determined at $40^{\circ} \mathrm{C}$ by increasing in $A 420 \mathrm{~nm}\left(\varepsilon_{\max }=36,000 \mathrm{M}^{-1} \mathrm{~cm}^{-1}\right)$. One unit of enzyme activity is defined as $1 \mu \mathrm{mol}$ of product formed per min.

\section{PCR amplification and sequencing of 5.8S-ITS of rDNA}

Fungal DNA was extracted from lyophilized mycelia of selected strains according to a protocol previously reported (Tapia-Tussell et al., 2006). PCR amplification of the internal transcribed spacer (ITS) region of the ribosomal DNA was performed using primers ITS1 and ITS4 (White et al., 1990) and PCR products (650 bp) were purified and sequenced by Macrogen Inc, Korea.

\section{Sequence analysis and phylogenetic inference}

Sequence alignment was done with ClustalW (Thompson et al., 1994) and taxonomic classification and nearest neighbors were evaluated with GenBank database using BLAST (Altschul et al., 1997). Phylogenetic inferences were carried out following the maximum parsimony method by using bootstrap values based on 1000 replications with program MEGA 4 (Tamura et al., 2007). Only parsimony informative sites were considered for analysis.

\section{Microbial treatment of textile dyes}

The strain with the highest laccase activity $(\mathrm{Bm}-2)$ was used for the evaluation of textile dye decolourization. Erlenmeyer flasks containing $200 \mathrm{ml}$ of liquid ME supplemented with $0.01 \%$ of each textile dye (acid blue 74, reactive green 19 and reactive red 195 dyes) were inoculated with $4 \mathrm{ml}$ of homogenized inoculum from selected fungi and incubated at $35^{\circ} \mathrm{C}$ in a shaker $(150 \mathrm{rpm})$ for three days. Samples were withdrawn at regular intervals $(0,24,48$ 
Table 1. Screening of strains for laccase production by ABTS oxidation.

\begin{tabular}{ll}
\hline Strain & Size of halo $(\mathrm{cm})$ \\
\hline Bm-2 & 5.8 \\
Bm-4 & $-^{\star}$ \\
Bm-5 & $-^{\star}$ \\
AHB-1 & 4.6 \\
AHB-3 & 3.3 \\
AHB-6 & 6.5 \\
VIC-3 & 4.4 \\
\hline
\end{tabular}

*No halo formation.

and $72 \mathrm{~h}$ ) and analysed for laccase activity (as previously described) and colour removal. Non-inoculated controls were run under the same conditions. Decolouration was determined as a percentage of the absorbance reduction at the wavelength of maximum absorbance for each eye. Rate colour removal $(P)$ was calculated as follows: $P=\left(A_{1}-A_{2}\right) / A_{1} \times 100 \%$, where $A_{1}$ represents the absorbency of the control without inoculums and $A_{2}$ represents the absorbency of samples.

\section{RESULTS}

\section{Primary screening for ligninolytic activity}

From a total of 36 fungal strains autochthonous to Yucatan tested by the ABTS oxidation-based method, three isolates from henequen by-products and four from wood decay showed high ABTS oxidation capacity in agar plates (Table 1), as demonstrated by the dark green colour observed in the plates.

In the case of Bm-4 and Bm-5 strains, no extracellular laccase activity was produced since no halo formation was observed, but at the end of mycelia growing, ABTS oxidation was observed below the fungal colony what might suggest that laccase activity in these isolates would be associated to cell wall.

In Figure 1, strains with the highest oxidative activity isolated from henequen by-products (AHB-6) and wood decay $(\mathrm{Bm}-2)$ are shown. These results indicated that the plate assay can be used as a simple rapid assay for visual demonstration of presence of laccase.

\section{PCR-fingerprinting}

AP-PCR analysis performed with six arbitrary primers to characterize seven fungi isolation is shown in Table 2. As can be seen, the resulting patterns for each strain are different to all primers; a different letter (A to $F$ ) was given to each combination of pattern type, except for strains $\mathrm{Bm}-4$ and $\mathrm{Bm}-5$ which were identical in all cases. Band patterns obtained from single primers varied from simple patterns consisting of 1 to 4 bands to complex consisting of up to 12 bands (Figure 2). In spite of the fact that the detected level of polymorphism was generally high with all primers tested, $\mathrm{CAG}_{5}$ (Figure $2 \mathrm{a}$ ) and $\mathrm{GACAC}_{3}$ (Figure 2c) revealed the highest differences among isolates and gave the highest levels of resolution for all primers.

\section{Production of laccase}

The different levels of laccase production in liquid medium for the seven strains selected are shown in Figure 3. The highest levels of laccase production were obtained for strains Bm-2 and AHB-6, which produce high titres of laccase activity without the addition of mediators coinciding with results obtained for plaque activity (Figure 1), while strains $B m-4$ and $B m-5$ did not produce extracellular laccase and were indistinguishable at molecular level suggesting that these two isolates are redundant. In the case of strains AHB-1, AHB-3 and VIC-3, the levels of laccase production were low, they were in the range of 2.5 to $5 \mathrm{U} / \mathrm{ml}$.

\section{PCR amplification, sequencing of 5.8S-ITS of rDNA and phylogenetic inference}

The amplified fragment from the 5.8S-ITS region for seven selected isolates was $650 \mathrm{bp}$ long. Sequence analyses showed a similarity level of 97 to $99 \%$ to other sequences from different species belong to Basidiomycota and Ascomycota. Bm-2 and AHB-6 had a $98 \%$ of homology with Trametes hirsuta, meanwhile Bm4 and $\mathrm{Bm}-5$ had $99 \%$ of similarity with Phanerochaete chrysosporium. This result supports the hypothesis that $B m-4$ and $B m-5$ are the same strain.

The other three isolates AHB-1, AHB-3 and VIC-3 were identified as Cochliobolus lunatus, Athelia rolfsii and Bipolaris sp with 99, 97 and 99\% of homology, respectively. These species are plant pathogens.

As can be observed in the consensus tree depicted in Figure 4, all strains grouped in different clades indicating that these isolates belong to different taxonomic ranks with high support (100 and 95\%) in the branches. All strains identified in this study grouped were with other from the same species. In the case of $T$. hirsuta, strains Bm-2 (GQ280373) and AHB-6 (GQ280372), although, they are the same species grouped in different clades.

\section{Microbial treatment of textile dyes}

The ability of Bm-2 identify as $T$. hirsuta to decolourize three synthetic (one indigoid and two azo) dyes in a liquid medium was evaluated. Although, the decolourization rates of all dyes were different, in all cases a high rate of decolourization was observed (Figure 5a). Bm-2 started to decolourize acid blue 74 immediately after growth commenced, with a colour removal of $50 \%$ at $24 \mathrm{~h}$ and reaching $90 \%$ after $48 \mathrm{~h}$ (Figure $5 \mathrm{a}, \mathrm{b}$ ). In the medium 

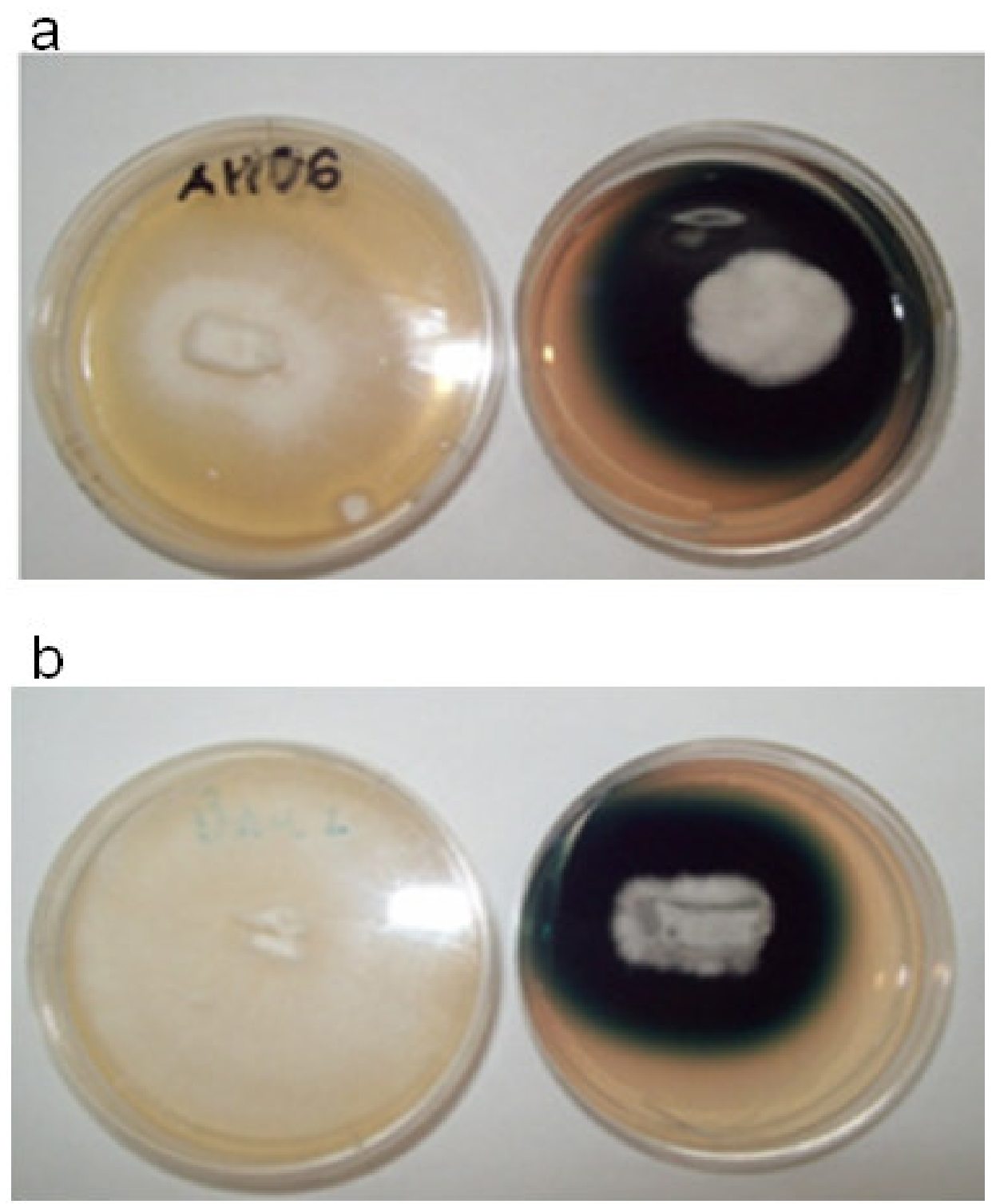

Figure 1. Primary screening for ligninolytic activity in plates. (a) T. hirsuta, AHB-6 strain isolated from henequen by-products, in the left media without ABTS (control), in the right media with ABTS; (b) $T$. hirsuta Bm-2 strain isolated from wood decay, in the left media without ABTS (control), in the right media with ABTS.

Table 2. AP-PCR pattern of ligninolytic fungi strains. The last column, overall pattern, was obtained from the combination of the results from the different primers. A different letter was given to each combination of pattern types.

\begin{tabular}{|c|c|c|c|c|c|c|c|}
\hline \multirow{2}{*}{ Strain } & \multicolumn{6}{|c|}{ AP-PCR with primer } & \multirow{2}{*}{$\begin{array}{l}\text { Overall } \\
\text { pattern }\end{array}$} \\
\hline & $(\mathrm{GTG})_{5}$ & M13 & $(\mathrm{GAC})_{5}$ & $(\mathrm{CAG})_{5}$ & $(\mathrm{TTC})_{5}$ & $(\text { GACAC })_{3}$ & \\
\hline Bm-2 & A & A & A & A & A & A & A \\
\hline $\mathrm{Bm}-4$ & $\mathrm{~B}$ & $B$ & $\mathrm{~B}$ & $\mathrm{~B}$ & $\mathrm{~B}$ & $\mathrm{~B}$ & $\mathrm{~B}$ \\
\hline $\mathrm{Bm}-5$ & $\mathrm{~B}$ & $\mathrm{~B}$ & $\mathrm{~B}$ & $\mathrm{~B}$ & $\mathrm{~B}$ & B & $B$ \\
\hline AHB-1 & C & C & C & C & C & C & C \\
\hline AHB-3 & D & D & D & D & D & D & D \\
\hline AHB-6 & $\mathrm{E}$ & E & $\mathrm{E}$ & $\mathrm{E}$ & $E$ & E & $E$ \\
\hline VIC-3 & $\mathrm{F}$ & $\mathrm{F}$ & $\mathrm{F}$ & $\mathrm{F}$ & $\mathrm{F}$ & $\mathrm{F}$ & $\mathrm{F}$ \\
\hline
\end{tabular}



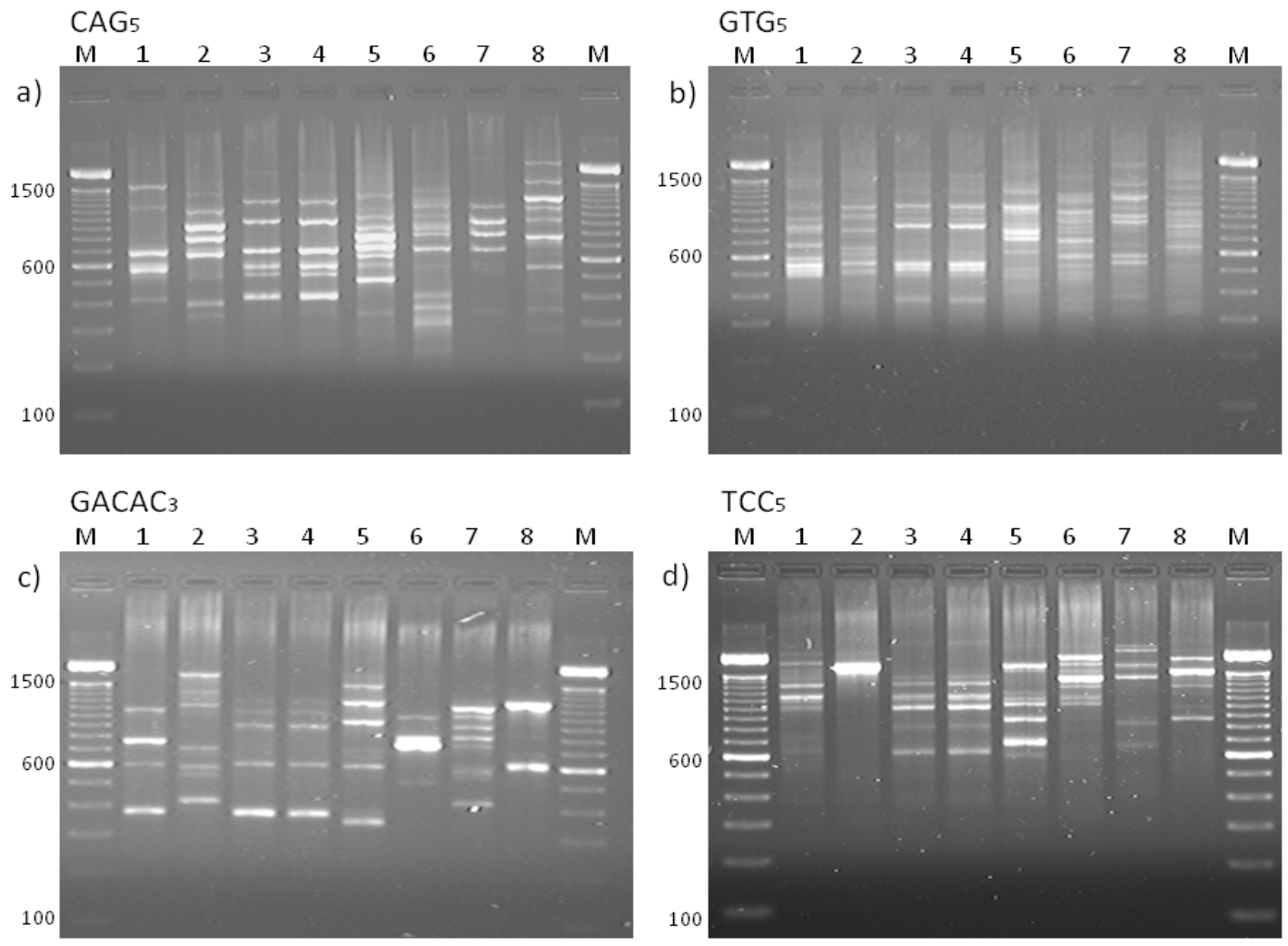

Figure 2. PCR-fingerprinting of fungal strains with different primers. M: molecular marker 100 bp ladder; Lane 1: P. chrysosporium (control); lane 2: Bm-2; lane 3: Bm-4, lane 4: Bm-5, lane 5: AHB-1, lane 6: AHB3, lane 7: AHB-6 and lane 8: VIC-3.

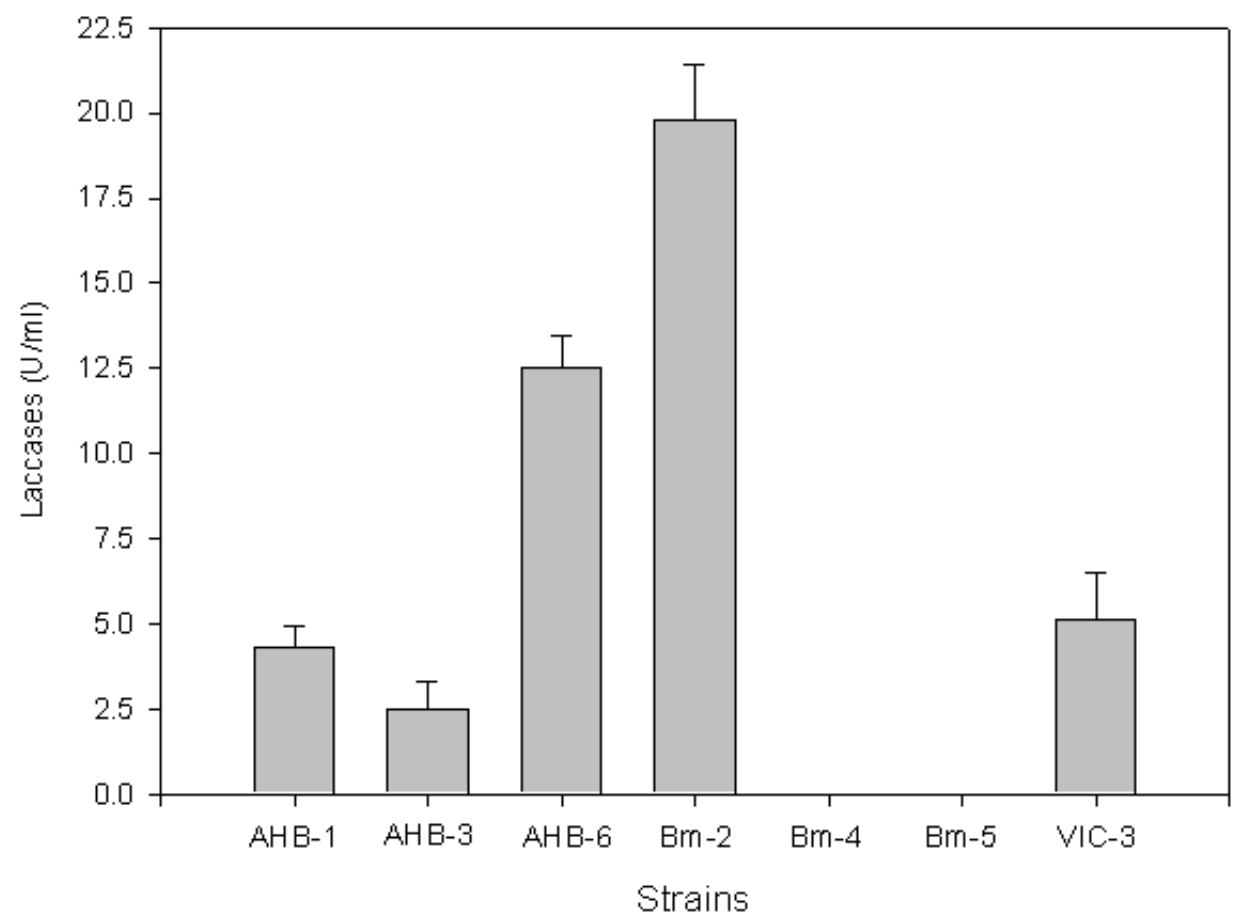

Figure 3. Laccase production by seven white rot fungi strains, AHB-1:C. lunatus, AHB-3 A. rolfsii, AHB-6 and Bm-2:T. hirsuta, Bm-4 and Bm-5: P. chrysosporium, VIC-3: Bipolaris sp. 


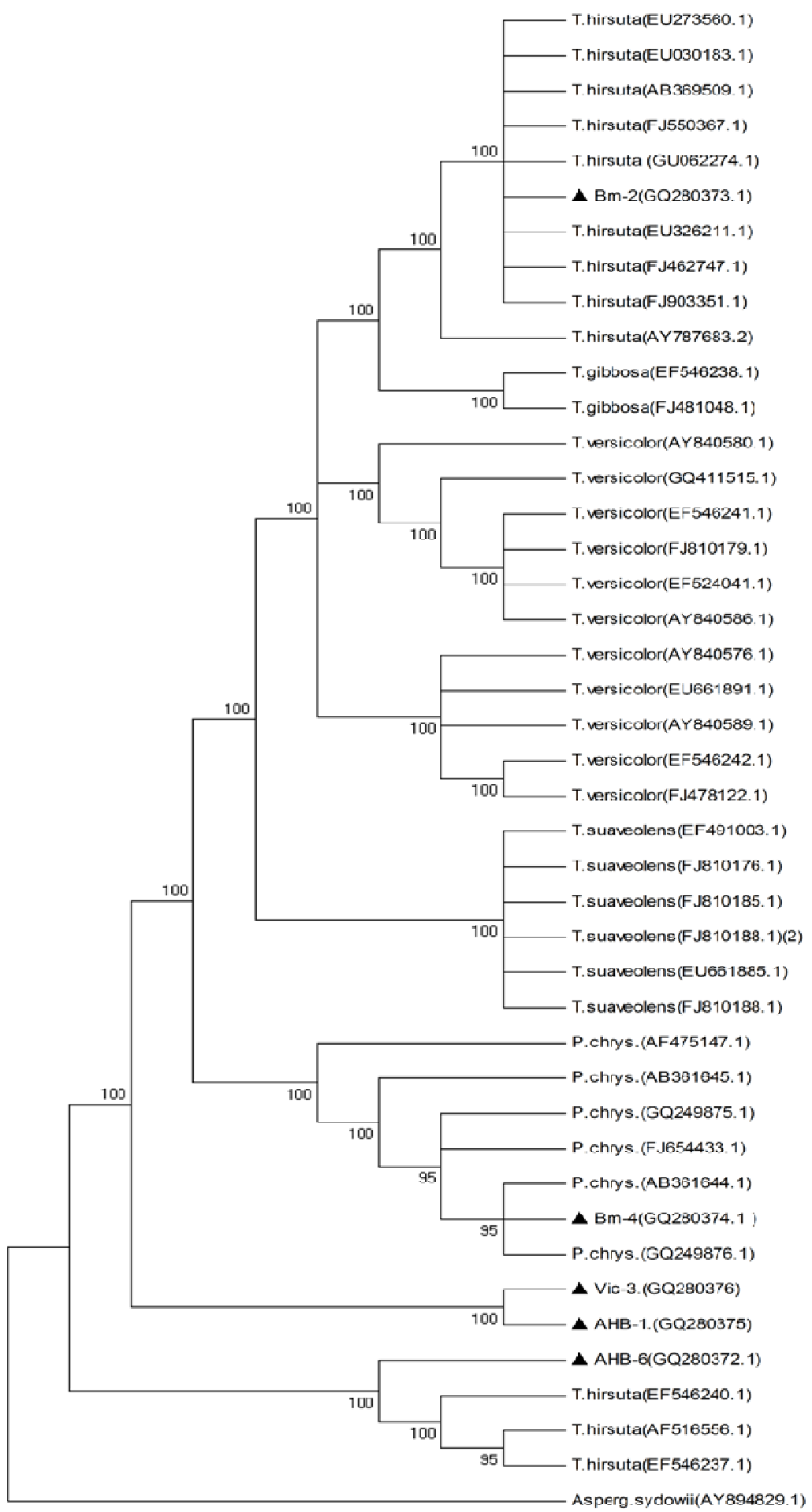

Figure 4. The evolutionary history was inferred using the maximum parsimony method (Eck and Dayhoff, 1966). The consensus tree inferred from 86 most parsimonious trees is shown. Branches corresponding to partitions reproduced in less than $50 \%$ trees are collapsed. The consistency index is $(0.867277)$, the retention index is $(0.949345)$ and the composite index is $0.826712(0.823345)$ for all sites and parsimony-informative sites (in parentheses). The percentage of parsimonious trees in which the associated taxa clustered together is shown next to the branches. There were a total of 240 positions in the final dataset, out of which 217 were parsimony informative. Aspergillus sydowii (AY 894829.1) was employed as the out-group to root the tree. Strains used in this study. 
a)

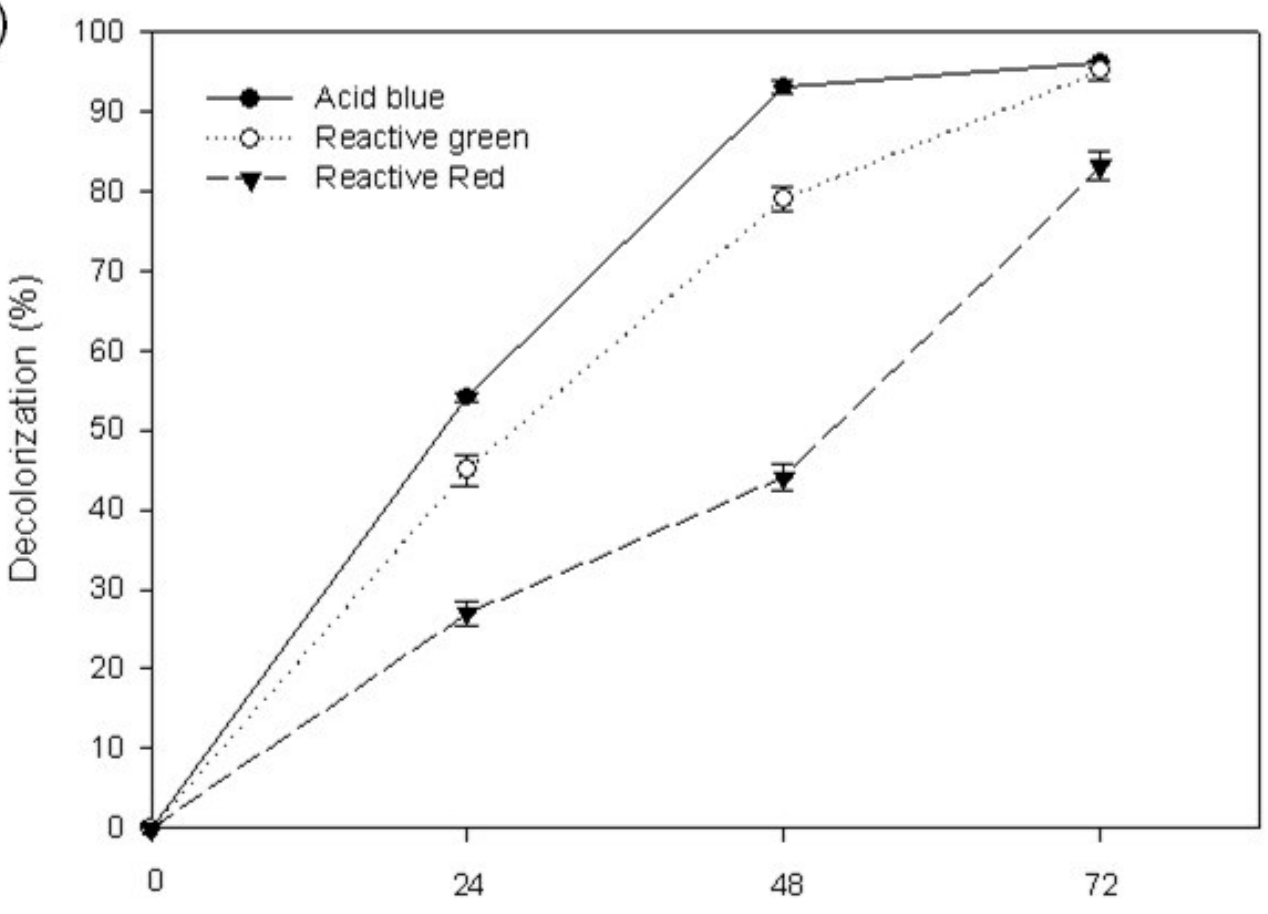

Time (h)

b)
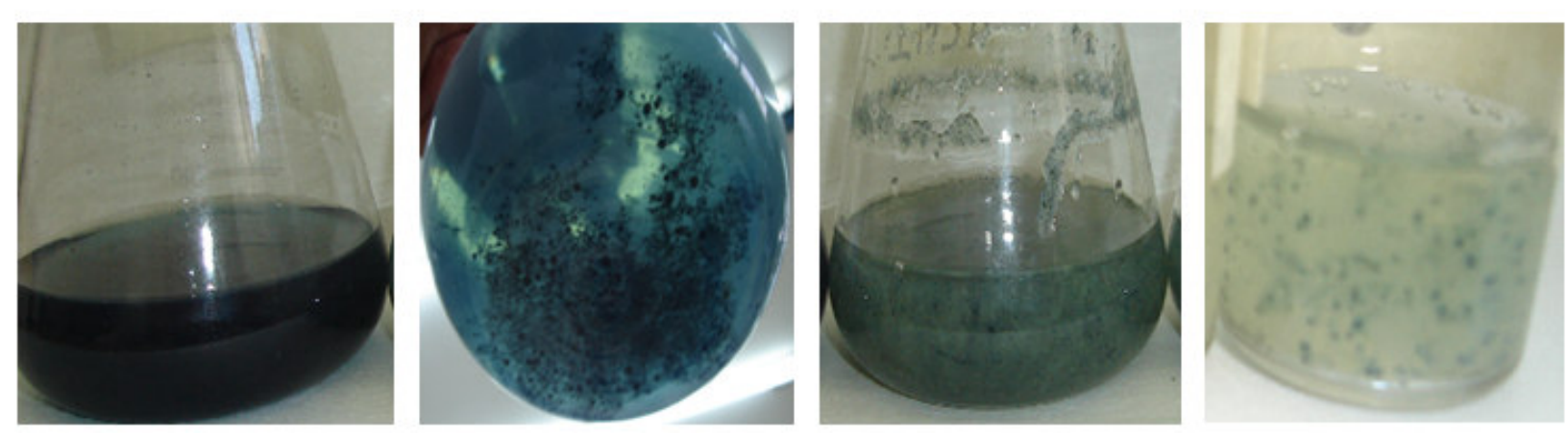

Figure 5. (a) Decolourization (\%) of three commercial textile dyes (acid blue 74, reactive green 19 and reactive red 195) with $\mathrm{Bm}-2$ ( T. hirsuta); (b) Acid blue 74 dye decolourized by Bm-2 (T. hirsuta).

with added green reactive 19, a decolourization of $95 \%$ was achieved at $72 \mathrm{~h}$ and after the same time, the medium containing red reactive 195 showed a colour removal of $83 \%$. In the case of reactive red 195 , decolourization at 24 and $48 \mathrm{~h}$ was two folds lower than the other dyes decolourization. Non-inoculated controls showed no colour removal.

\section{DISCUSSION}

In this study, there were identified and characterized seven fungi from different environments in Yucatan Peninsula. Few papers have been published dealing with the geographical and climatic distribution of autochthonous fungal species or describing the biodiversity in a given region for ligninolytic activity production (Dhouib et al., 2005; Saparrat et al., 2002). Most of the screening surveys for ligninolytic enzyme producers have been carried out on culture collection strains (Jaouani et al., 2005).

PCR fingerprinting approach using the simple repeat primers proved to be useful in discriminating at species and subspecies level (Van der Vossen et al., 2003), a fact also demonstrated for other author (Libkind, 2007), using the same set of primers. The variation in band patterns obtained with all AP primers used, suggests that the full set of these primers may be suitable as "universal" primer set in order to obtain white rot fungi fingerprints. 
ITS sequence-based identification for fungal isolates has been successfully used for other species (Perez-Brito et al., 2007; Talhinhas et al., 2002; Than et al., 2008) and in this study, it is further supported by a phylogenetic analysis based on a maximum parsimony method.

Although, there are few reports of high laccase production for basidiomycetous fungi in initial screenings (Baldrian, 2006; Dhouib et al., 2005), it was found that the basidiomycetous strain $\mathrm{Bm}-2$ was the highest laccase producer. This strain, identified as $T$. hirsuta registered a higher laccase production after $72 \mathrm{~h}$ without addition of mediators in comparison with other strains of the same genus reported as high producers of this enzyme (Dhouib et al., 2005).

The strains AHB-1, AHB-3 and Vic-3, identified as $C$. lunatus, $A$. rolfsii and Bipolaris sp., respectively, produced the lowest levels of laccase, possibly due to the requirement of inductors or a dependency on a physiological role for this enzyme in nature, in the host colonization process. These strains are maize phytopathogens and the laccases may represent factors of virulence during invasion of the plants (Baldrian, 2006).

Strains $\mathrm{Bm}-4$ and $\mathrm{Bm}-5$, identified as redundant isolates of Phanerochaete chrysosporium did not produce extracellular laccases. Oxidation zones formed in plate assays could be associated with laccases attached to the cell wall or to the presence of other ligninolytic activities such as manganese or peroxidase ligninase. Laccase production in $P$. crysosporium also needs clarification. Although, $P$. crysosporium has been reported as white rot fungi not capable to produce laccase, this enzyme has been detected in cultures of this fungus supplemented with cellulose (Srinivasan et al., 1995). However, due to the absence of laccase genes, some researchers (Larrondo et al., 2003) have associated its activity with the action of another multicopper oxidase.

Although, strains Bm-2 and AHB-6 (classified as $T$. hirsuta) shared similarities to sequences from same species they grouped in different clades. One explanation could be the differences in their habitat, because one (AHB-6) was isolated from henequen by products, this environment is characterized by very acid soils and high contents of organic acids and another $(\mathrm{Bm}-2)$ was isolated from wood decay in deciduous forest, suggesting that $\mathrm{Bm}-2$ and AHB-6 might represent two different ecotypes of $T$. hirsuta (Kihara and Kumagai, 1994) characterized by possessing differences in extracellular laccase activity and textile dye decolourization rates (S. Solis-Pereira, unpublished data).

Dye decolourization by ligninolytic fungi has been associated with extracellular laccase activity in various studies (Abadulla et al., 2000; Minussi et al., 2001; Salony et al., 2006). In this study, a direct relationship between extracellular production of laccases by $T$. hirsuta (Bm-2 strain) and the decolourization of the three dyes was also found.

These findings are supported by a recent study in which $T$. hirsuta laccase was able to decolorize simulated Congo Red and Remazol Brilliant Blue R dye baths (91 and $45 \%$, respectively) in $19.5 \mathrm{~h}$ without mediators (Moilanen et al., 2010) and a previous report where $T$. hirsuta and a purified laccase from this organism were able to degrade triarylmethane, indigoid, azo and anthraquinonic dyes (Abadulla et al., 2000).

The rate of decolourization of acid blue 74 (indigoid type of dye) was twofold faster than the azo dye (reactive red 195); this is in agreement with the results reported previously for T. hirsuta (Abadulla et al., 2000), it could be explained by the differences in chemical structure of these dyes.

In this study, the ability of $T$. hirsuta to decolorize without any mediators, three structurally different dyes were proved. These results suggest the potential of this fungus to be used in color removal of textile dye effluents. Considering that in large scale applications, the use of mediators can be expensive and to have a laccase which can work without mediators could be useful.Further studies focusing on laccase genes in order to obtain a high expression of this enzyme should be carried out.

\section{ACKNOWLEDGEMENT}

The authors would like to thank Rodolfo Martin-Mex for statistical analysis.

\section{REFERENCES}

Abadulla E, Tzanov T, Costa S, Robra KH, Cavaco-Paulo A, Gübitz GM (2000). Decolourization and detoxification of textile dyes with a laccase from Trametes hirsuta. Appl. Environ. Microbiol. 66: 33573362.

Altschul SF, Madden TL, Schaffer AA, Zhang J, Zhang Z, Miller W, Lipman DJ (1997). Gapped BLAST and PSI-BLAST: a new generation of protein database search programs. Nucleic Acids Res. 25: 3389-3402.

Baldrian P (2006). Fungal laccases-occurrence and properties. FEMS Microbiol. Rev. 30: 215-242.

Bridge PD, Pearce DA, Rivera A, Rutherford MA (1997). VNTR derived oligonucleotides as PCR primers for population studies in filamentous fungi. Lett. Appl. Microbiol. 24: 426-430.

Cadez N, Raspor P, de Cock AWAM, Boekhout T, Smith MT (2002). Molecular identification and genetic diversity within species of the genera Hanseniaspora and Kloeckera. FEMS Yeast Res. 1: 279-289.

Cristovão RO, Tavares AP, Ferreira LA, Loureiro JM, Boaventura RA, Macedo EA (2008). Modeling the discolouration of a mixture of reactive textile dyes by commercial laccase. Bioresour. Technol. 100: 1094-1099.

Dhouib A, Hamza M, Zouari H, Mechichi T, Hmidi R, Labat M, Martínez MJ, Sayadi S (2005). Screening for ligninolytic enzyme production by diverse fungi from Tunisia. World J. Microb. Biot. 21: 1415-1423.

Eck RV, Dayhoff MO (1966). Atlas of Protein Sequence and Structure. National Biomedical Research Foundation, Silver Springs, Maryland.

Fleet GH (1992). The microorganisms of winemaking-isolation, enumeration and identification. In: Fleet GH (ed) Wine

Microbiology and Biotechnology, Harwood Academic Publishers, Camberwell, Australia, pp. 1-27.

Hong YZ, Xiao YZ, Zhou HM, Fang W, Zhang M, Zhu J, Wang J, Wu LJ, Yu ZL (2006). Expression of a laccase cDNA from Trametes sp. AH28-2 in Pichia pastoris and mutagenesis of transformants by 
nitrogen ion implantation. FEMS Microbiol. Lett. 258: 96-101.

Jaouani A, Guillen F, Penninckx MJ, Martínez AT, Martínez MJ (2005). Role of Pycnoporus coccineus laccase in the degradation of aromatic compounds in olive oil mill wastewater. Enzyme Microb. Technol. 36: 478-486.

Kihara J, Kumagai T (1994). Ecotypes of the fungus Bipolaris oryzae with various responses of the mycochrome system. Physiol. Plantarum, 92: 689-695.

Kurtzman CP, Boekhout T, Robert V, Fell JW, Deak T (2003). Methods to identify yeasts. In: Boekhout $\mathrm{T}$, Robert $\mathrm{V}$ (eds). Yeasts in Food: Beneficial and Detrimental Aspects, Woodhead Publishing, Cambridge, U.K. pp. 69-121.

Larrondo LF, Salas L, Melo F, Vicuna R, Cullen D (2003). A novel extracellular multicopper oxidase from Phanerochaete chrysosporium with ferroxidase activity. Appl. Environ. Microbiol. 69: 6257-6263.

Leaw SN, Chang HC, Sun HF, Barton R, Bouchara JP, Chang TC (2006). Identification of medically important yeast species by sequence analysis of the internal transcribed spacer regions. J. Clin. Microbiol. 44: 693-699.

Levin L, Papinutti L, Forchiassin F (2004). Evaluation of Argentinian white rot fungi for their ability to produce lignin-modifying enzymes and decolourize industrial dyes. Bioresour. Technol. 94: 169-176.

Libkind D (2007). Evaluación de la técnica de MSP-PCR para la caracterización molecular de aislamientos de Rhodotorula mucilaginosa provenientes de la Patagonia noroccidental. Rev. Argent. Microbiol. 39: 133-137.

Matsumura E, Shin T, Murao S, Yamamoto E, Kawano T (1987) New enzymatic colorimetric reactions of benzoic acid derivatives with ABTS 2,2'-azinobis-3-ethylbenzthiazoline-6-sulfonic acid diamomonium salt in the presence of laccase. Agric. Biol. Chem. 51: 2743-2750

Minussi RC, de Moraes SG, Pastore GM, Duran N (2001). Biodecolourization screening of synthetic dyes by four white-rot fungi in a solid medium: possible rol of siderophores. Lett. Appl. Microbiol. 33: 21-25.

Moilanen U, Osma JF, Winquist E, Leisola M, Rodriguez S (2010). Decolorization of simulated textile dye baths by crude laccases from Trametes hirsuta and Cerrena unicolor. Eng. Life Sci. 10: 242-247.

Pal M, Calvo AM, Terron MC, Gonzalez AE (1995). Solid-state fermentation of sugarcane burgesses with Flammulina velutipes and Trametes versicolour. World J. Microb. Biot. 11: 541-545.

Peláez F, Martínez MJ, Martínez AT (1995). Screening of 68 species of basidiomycetes for enzymes involved in lignin biodegradation. Mycol. Res. 99: 37-42.

Perez-Brito D, Tapia-Tussell R, Quijano-Ramayo A, Larque-Saavedra A, Lappe P (2007). Molecular characterization of Kluyveromyces marxianus strains isolated from Agave fourcroydes (Lem.) in Yucatan, Mexico. Mol. Biotechnol. 37: 181-186.

Reddy CA (1995). The potential for white rot fungi in the treatment of pollutants. Curr. Opin. Biotechnol. 6: 320-328.

Robinson T, Chandran B, Nigam P (2001). Studies on the production of enzymes by white-rot fungi for the decolorization of textile dyes. Enzyme. Microb. Technol. 29: 575-579.

Rodriguez E, Pickard MA, Vazquez-Duhalt R (1999). Industrial dye decolourization by laccases from ligninolytic fungi. Curr. Microbiol. 38: 27-32.

Rodriguez S, Sanroman M, Gübitz GM (2005). Influence of redox mediators and metal ions on synthetic acid dye decolourization by crude laccase from Trametes hirsuta. Chemosphere, 58: 417-422.

Salony, Mishra S, Bisaria VS (2006). Production and characterization of laccase from Cyathus bulleri and its use in decolourization of recalcitrant textile dyes. Appl. Microbiol. Biot. 71: 646-653.
Saparrat MCN, Guillén F, Arambarri AM, Martínez AT, Martínez MJ (2002). Induction, isolation and characterization of two laccases from the white rot basidiomycete Coriolopsis rigida. Appl. Environ. Microb. 68: 1534-1540.

Srinivasan C, D'Sousa TM, Boominathan K, Reddy CA (1995). Demonstration of laccase in white rot basidiomycete Phanerochaete chrysosporium BKM-F1767. Appl. Environ. Microb. 61: 4274-4277.

Talhinhas P, Sreenivasaprasad S, Neves-Martin J, Oliveira H (2002). Genetic and morphological characterization of Colletotrichum acutatum causing anthracnose of lupins. Phytopathology, 92: 986996.

Tamura K, Dudley J, Nei M, Kumar S (2007). MEGA 4: Molecular Evolutionary Genetics Analysis (MEGA) software version 4.0. Mol. Biol. Evol. 24: 1596-1599.

Tapia-Tussell R, Lappe P, Ulloa M, Quijano-Ramayo A, Caceres-Farfan M, Larque-Saavedra A, Perez-Brito D (2006). A rapid and simple method for DNA extraction from yeast and fungi isolated from Agave fourcroydes. Mol. Biotechnol. 33: 67-70.

Tapia-Tussell R, Quijano-Ramayo A, Cortes-Velazquez A, Lappe P, Larqué-Saavedra A, Pérez-Brito D (2008). PCR-based Detection and Characterization of the Fungal Pathogens Colletotrichum gloeosporioides and Colletotrichum capsici Causing Anthracnose in Papaya (Carica papaya L.) in the Yucatan Peninsula. Mol. Biotechnol. 40: 293-298.

Tavares APM, Cristovão RO, Gamelas JAF, Loureiro JM, Boaventura RAR, Macedo EA (2009). Sequential decolourization of reactive textile dyes by laccase mediator system. J. Chem. Technol. Biot. 84: 442-446.

Than PP, Jeewon R, Hyde KD, Pongsupasamit R, Mongkolporn O, Taylor PWJ (2008). Characterization and pathiogenicity of Colletotrichum species associated with anthracnose on chilli (Capsicum sp) in Thailand. Plant Pathol. 57: 562-572.

Thompson JD, Higgins DG, Gibson TJ (1994). CLUSTAL W: improving the sensitivity of progressive multiple sequence alignment through sequence weighting, position-specific gap penalties and weight matrix choice. Nucleic. Acids. Res. 22: 4673-4680.

Tien M, Kirk K (1984). Lignin-degrading enzymes from Phanerochaete chrysosporium: purification, characterization, and catalytic properties of a unique $\mathrm{H}_{2} \mathrm{O}_{2}$-requiring oxygenase. P. Natl. Acad. Sci. USA., 81: 2280-2284.

Torres E, Bustos-Jaimes I, Le Borgne S (2003). Potential use of oxidative enzymes for detoxification of organic pollutants. Appl. Catal. B-Environ. 46: 1-15.

Van der Vossen JMBM, Rahaoui H, de Nijs MWCV, Hartog BJ (2003). PCR methods for tracing and detection of yeast in the food Chain. In Boekhout T, Robert V (eds) Yeast in Food. CRC press, Boca Ratón, Florida, USA, pp. 123-138.

White TJ, Bruns T, Lee S, Taylor JW (1990). Amplification and direct sequencing of fungal ribosomal RNA genes for phylogenetics. In: Innis MA, Gelfand DH, Sninsky JJ, White TJ (eds) PCR protocols: A guide to Methods and Applications. Academic Press, Inc, San Diego, California, pp. 315-322. 